\title{
Geochemical Assessment of the Biodegradation Levels of Some Crude Oils from Bayelsa State, Nigeria
}

\section{Oraegbunam CI*, Osuji LC and Onojake MC}

Petroleum Chemistry Research Group, Department of Pure and Industrial Chemistry, University of Port Harcourt, Nigeria

*Corresponding author: Oraegbunam Charles, Department of Pure and Industrial Chemistry, University of Port Harcourt, Choba, Rivers State, Nigeria, Tel: +2348030957672; Email: oray2k7@yahoo.com

\section{Research Article}

Volume 4 Issue 6

Received Date: November 25, 2020

Published Date: December 16, 2020

DOI: $10.23880 /$ ppej-16000243

\section{Abstract}

Coastal swamp crude oil samples obtained from Clough creek, Azuzuama and Tebidaba oil fields were analyzed to obtain their biodegradation rankings. The studied samples were fractionated by column chromatography into saturated and aromatic hydrocarbons. The saturated hydrocarbons were analyzed using Gas Chromatography-Mass Spectrometry (GC-MS). Some diagnostic ratios such as $\mathrm{C}_{30} \alpha \beta$ hopane/( $\left.\mathrm{Pr}+\mathrm{Ph}\right),(\mathrm{Pr}+\mathrm{Ph}) /\left(\mathrm{nC}_{17}+\mathrm{nC}_{18}\right)$ and $\mathrm{C}_{29} \alpha \beta_{25}$ norhopane/C $\mathrm{C}_{30} \alpha \beta$ hopane were $\mathrm{used}$ in assessing the biodegradation rankings. Though biodegradation was evident in the studied samples, their individual levels were compared based on these ratios. Assessment of the crude oil samples using $\mathrm{C}_{29} \alpha \beta 25$ norhopane/C $\mathrm{C}_{30} \alpha \beta$ hopane ratio show that the oils from AZU ST and TEB12 are more degraded when compared to oils from WELL 2. Consequently, (Pr+Ph)/ $\left(\mathrm{nC}_{17}+\mathrm{nC}_{18}\right.$ ratios show that TEB 12 is the most degraded while WELL 2 is the least degraded. AZU ST was also shown as the most degraded oil using $\mathrm{C}_{30} \alpha \beta$ hopane $/(\mathrm{Pr}+\mathrm{Ph})$ diagnostic ratio.

Keywords: Biomarker; n- alkanes; Biodegradation; Hopanes; Crude oil; Gas Chromatography

\section{Introduction}

Crude oil, a non-renewable source of energy is a complex mixture containing mostly hydrocarbons with varying proportions of organometallic compounds and non-hydrocarbon constituents. Crude oil contain numerous "chemical fossils" or "biomarker molecules" which are resistant to biodegradation and whose origin in the crude oil is related through transformation to organic molecules produced by living organisms [1].

Bacteria destroy alkanes, isoprenoid and biomarkers in source rock and crude oil; this bacterial activity effect on petroleum is termed Biodegradation. The process of microbial biodegradation in the oil reservoir has a dramatic effect on the fluid properties of hydrocarbons [2] as a result of temperature limits [3]. The loss of normal alkanes and acyclic isoprenoids (phytane and pristane) defines the starting process of biodegradation. Although a high biodegradation resistance is evident in terpanes and steranes, research has proved that under a severe process of weathering, these biomarkers can degrade to a certain degree (extensive microbial degradation) [4,5]. Wherein, the $\mathrm{Pr} / \mathrm{n}-\mathrm{C}_{17}$ ratio increases when the n-alkane level decreases [6].

Biomarker origin is traced back to formerly living organisms. Biological markers (Figure 1) as it is termed are found in sediments and rocks whose carbon structure is traced to living organisms. Biomarker fingerprinting has been adopted by petroleum geochemists in characterizing 


\section{Petroleum \& Petrochemical Engineering Journal}

crude oils to ascertain parameters including their level of biodegradation [7].

Several studies have been carried out successfully in the Niger Delta region using geochemical tools to characterize oils based on their standard biomarker ratios [8-10]. This paper examines the biodegradation rankings in oil samples obtained from Bayelsa State, Nigeria.

Below are structures of some aliphatic biomarkers resident in crude oil.

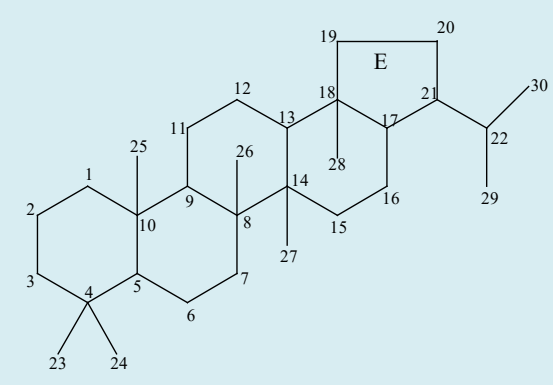

Hopane

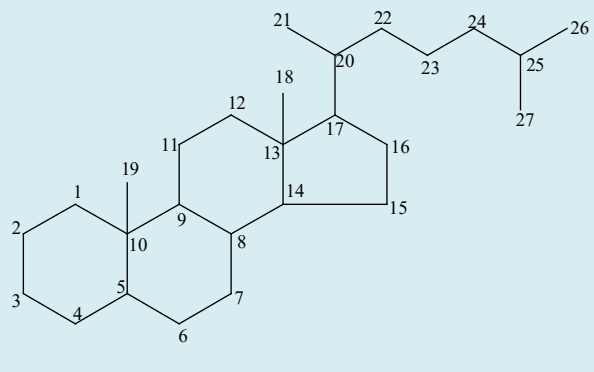

Cholestane $\mathrm{C}_{27}$

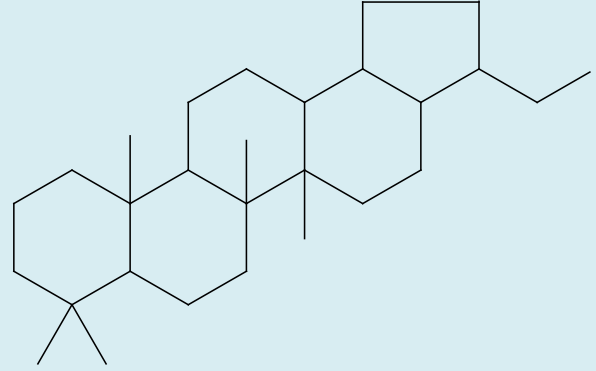

28, 30-Bisnorhopane

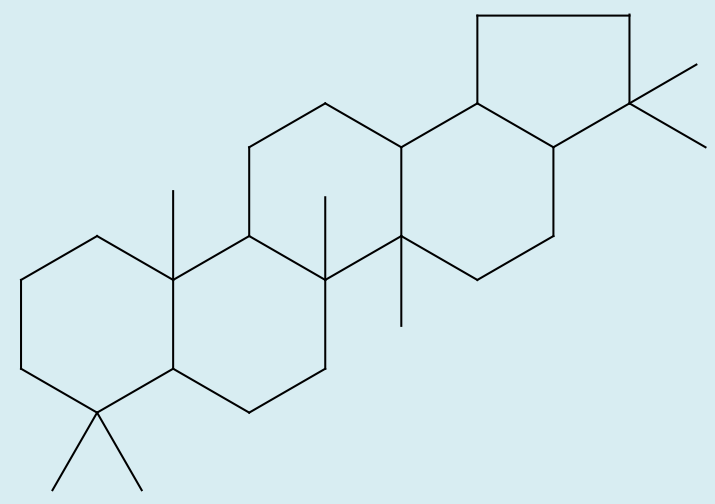

Gammacerane

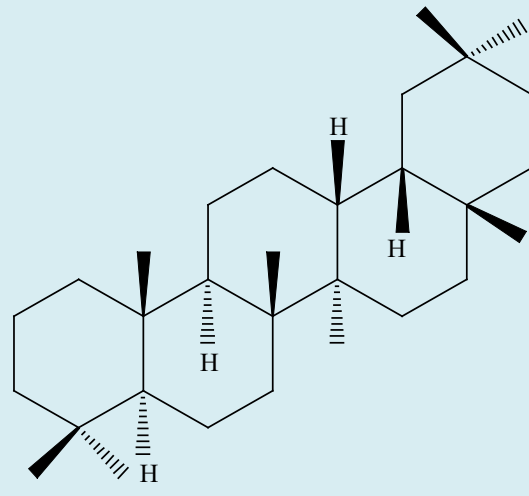

Olenane

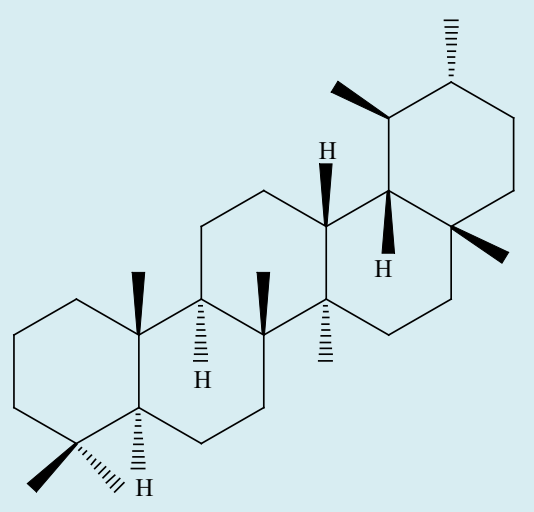

Ursane

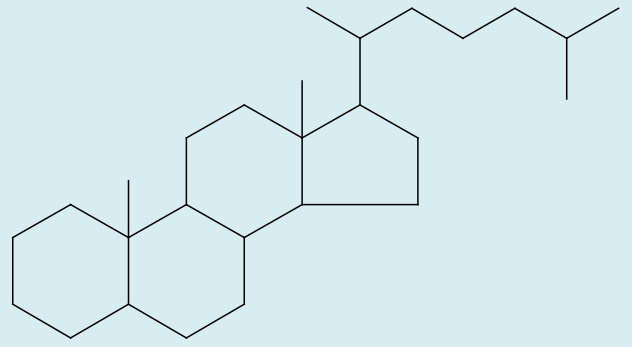

Ergostane $\mathrm{C}_{28}$

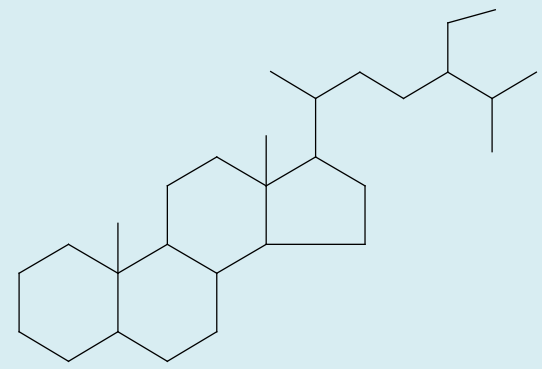

Sigmastane $\mathrm{C}_{29}$

Figure 1: Molecular structures of some biomarkers found in crude oil. 


\section{Petroleum \& Petrochemical Engineering Journal}

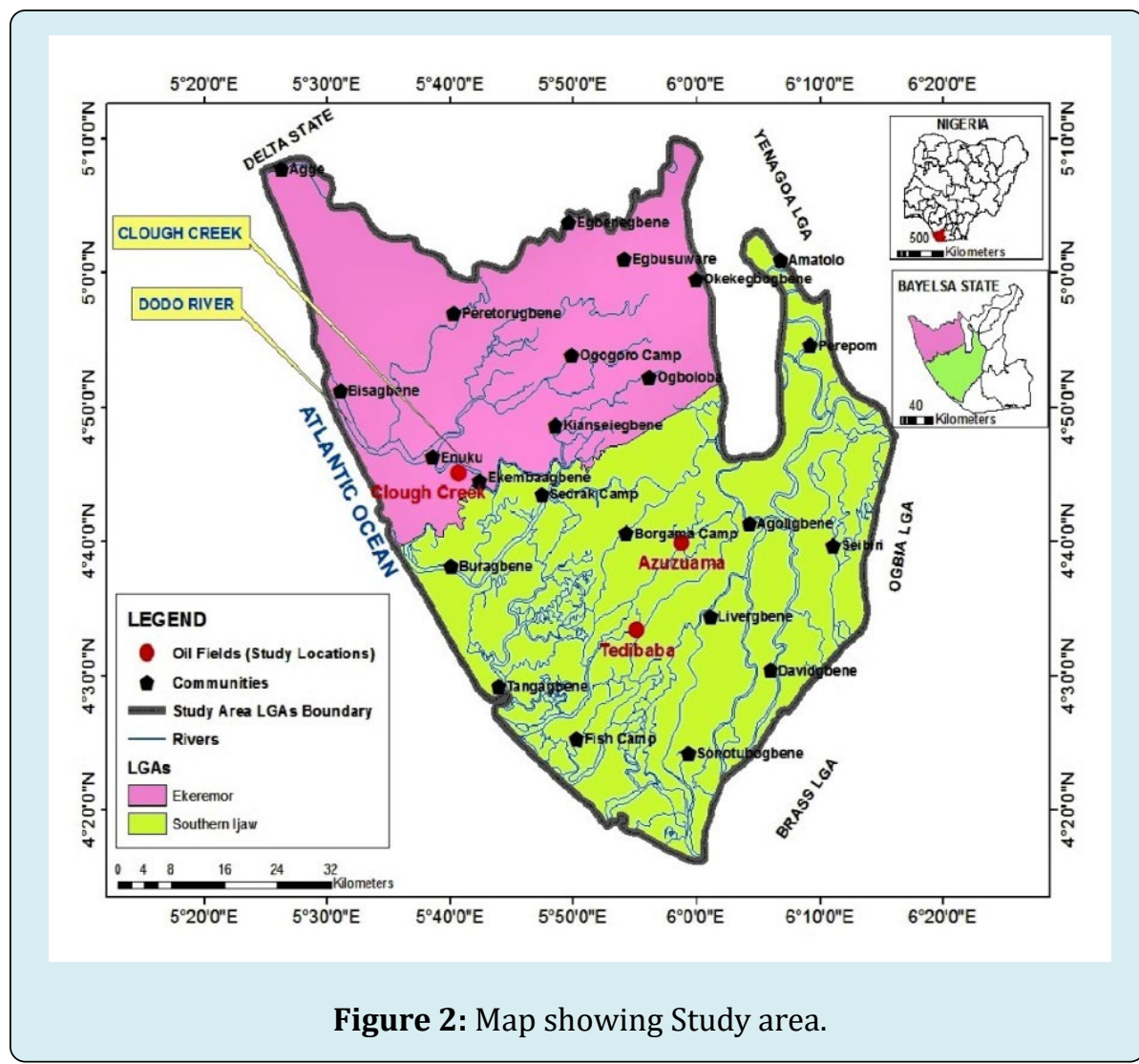

\section{Description of Study area}

Bayelsa state (Figure 2) is located in the Niger Delta region of southern Nigeria. A prolific area that houses one of the largest deposits of crude oil and natural gas in Nigeria. The geographical location is situated within latitudes $4 \hat{\mathrm{A}}^{\circ} 15^{\prime}$ North and $5 \hat{A}^{\circ} 23^{\prime}$ south and longitudes $5 \hat{A}^{\circ} 22^{\prime}$ West and $6 \hat{\mathrm{A}}^{\circ} 45^{\prime}$ East. Bayelsa is surrounded by the Atlantic ocean on the southern and western sides and states; Delta and Rivers on the northern and eastern regions respectively. Bayelsa State is located within the plains of the lower delta, assumed to have emanated via the Holocene of the quaternary period by the sedimentary deposits accumulation. The distinctive feature of the geological setting in bayelsa is the Sedimentary alluvium. The studied area formed due to numerous tributaries of River Niger in this plain and abandoned beach ridges; geological alterations still exist. Consequently, coastal beaches and tidal flats, flood plains are features that defines bayelsa as a lowland region. Characteristic features such as lagoons are also unique features of the bayelsa state. There are numerous streams of varying volumes and velocities in this unified area. These include Rivers Ekoli, Nun, Koluama, Brass etc. Most communities in Bayelsa state are surrounded by water thereby making access by road a bit difficult. This is characteristic of its estuarine and marine settings.

\section{Materials and Methods}

\section{Sample Collection, Preparation and Analysis}

The studied samples were collected from wellheads at Azuzuama, Tebidaba and Clough Creek fields in Bayelsa State, Nigeria (Figure 2) and are representatives of the oil bulk. They were labeled: AZU ST, WELL 2, TEB 12, TEB 08 and CCST respectively. These samples were retained in a glass vials and stored in a refrigerator for preservation until when needed for analysis.

$30 \mathrm{mg}$ of the oil sample was transferred to a $2 \mathrm{ml}$ bottle with Teflon lined plastic cork, and diluted with $1 \mathrm{ml}$ dichloromethane. The oil samples were fractionated and subjected to Gas Chromatography-Mass Spectrometry analysis. Abrakasa S [11] outlined the procedures used for the fractionation of oil samples. The saturated fractions were subjected to Gas Chromatography analysis using HP3890GC serial II, separation performed in a silica capillary column ( $30 \mathrm{~m} \times 0.25 \mathrm{~mm}$ id.) coated with $0.25 \mu \mathrm{m}, 5 \%$ phenyl methyl silicone (HP-5) by HP (Agilent United Kingdom). Hydrogen gas was used as carrier gas at $2 \mathrm{ml} / \mathrm{min}$ with a spilt/splitless injector, the temperature at $50^{\circ} \mathrm{C}$ for 2 mins then progressed at $4^{\circ} \mathrm{C} / \mathrm{min}$ to $300^{\circ} \mathrm{C}$ at which it is held for 20 mins (Table 1 ). 
Procedures and conditions for the GC-MS analysis were carried out as described by Onojake MC [12] at Giolee Global
Resources Limited, Port Harcourt (Figures 3-6).

\begin{tabular}{|c|c|c|c|c|c|}
\hline WELLS & $\mathbf{P r}$ & $\mathbf{P h}$ & $\mathbf{( P r}+\mathbf{P h}) /\left(\mathbf{n C}_{\mathbf{1 7}} \mathbf{+} \mathbf{n C}_{\mathbf{1 8}}\right.$ & $\mathbf{C}_{\mathbf{3 0}}$ Hopane $/(\mathbf{P r}+\mathbf{P h})$ & $\mathbf{C}_{\mathbf{2 9}}$ Norhopane $/ \mathbf{C}_{\mathbf{3 0}}$ Hopane \\
\hline AZU ST & 31.5 & 11.9 & 1.15 & 1.59 & 0.81 \\
\hline CCST & 22.27 & 69.93 & 0.81 & 0.48 & 0.78 \\
\hline TEB 12 & 30.58 & 83.31 & 1.26 & 0.54 & 0.81 \\
\hline TEB 08 & 16.68 & 97.98 & 1.03 & 0.41 & 0.73 \\
\hline WELL 2 & 46.37 & 25.14 & 0.64 & 0.84 & 0.43 \\
\hline
\end{tabular}

Table 1: Biodegradation parameters using Gas Chromatography- Mass Spectrometry.

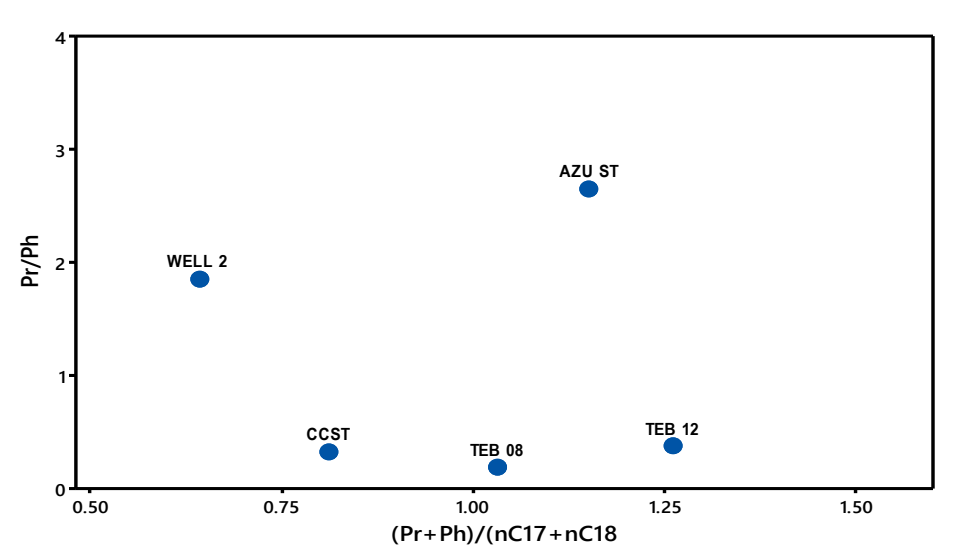

Figure 3: Biodegradation assessment using $(\mathrm{Pr}+\mathrm{Ph}) /\left(\mathrm{nC}_{17}+\mathrm{nC}_{18}\right)$.

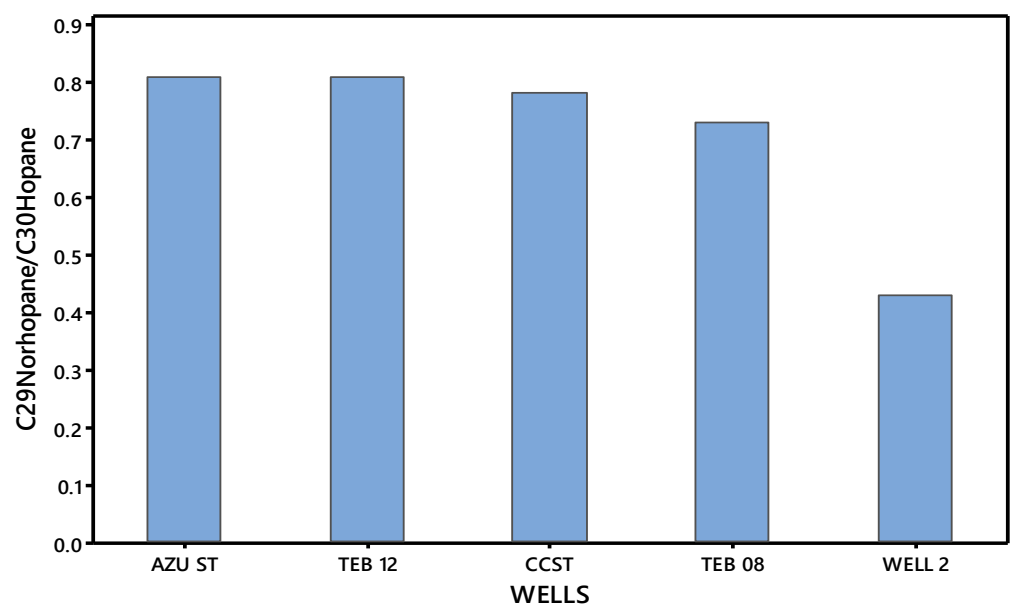

Figure 4: Biodegradation assessment using $\mathrm{C}_{30}$ Hopane/ $(\mathrm{Pr}+\mathrm{Ph})$. 
Petroleum \& Petrochemical Engineering Journal

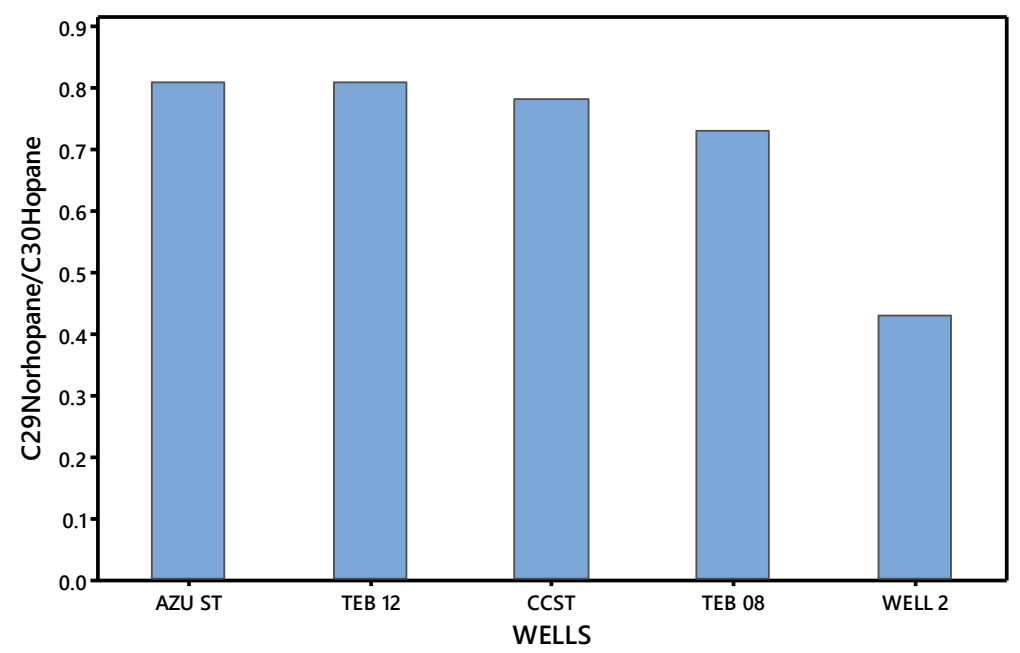

Figure 5: Biodegradation assessment plot using $\mathrm{C}_{29}$ Norhopane $/ \mathrm{C}_{30}$ Hopane.
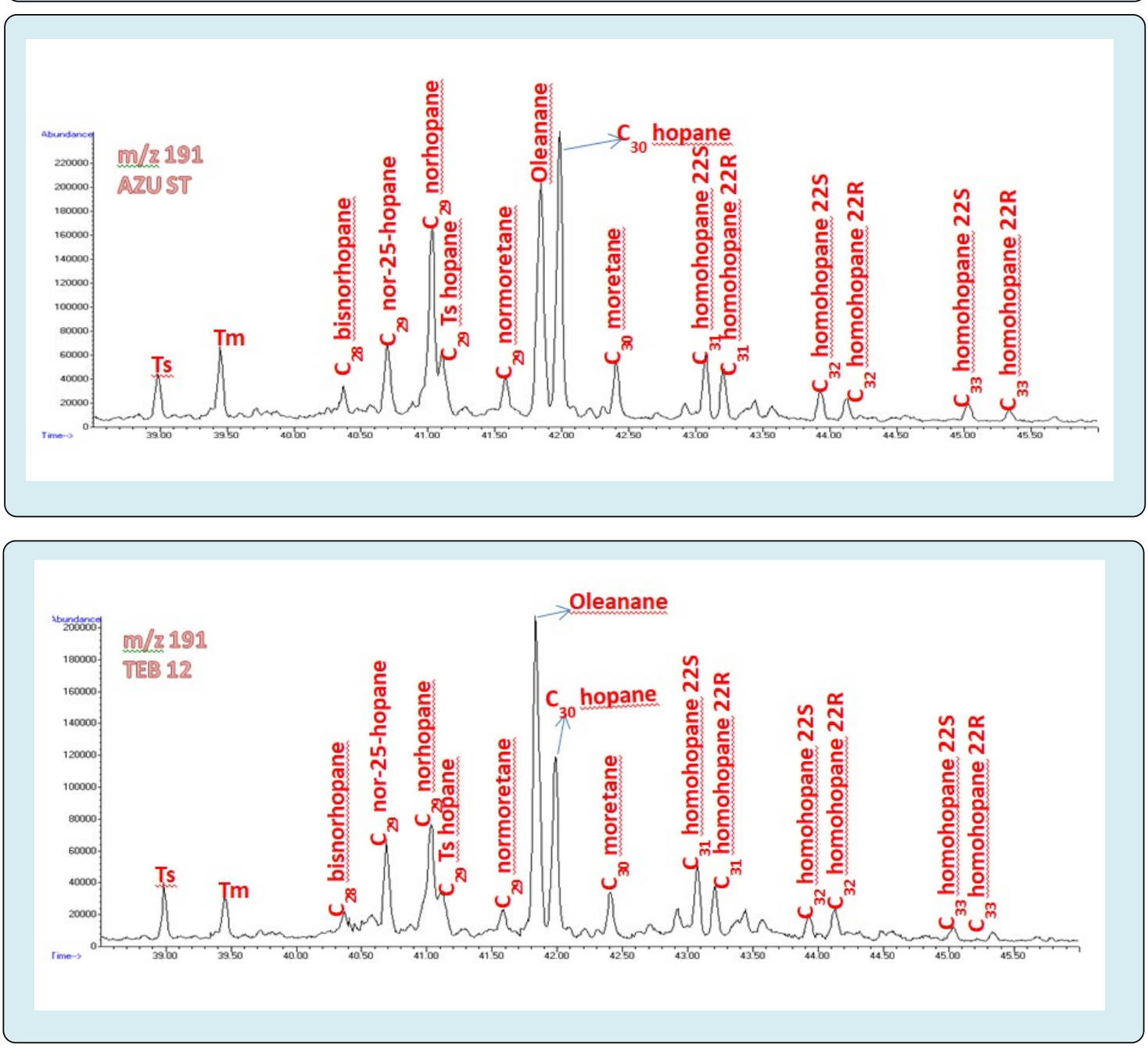


\section{Petroleum \& Petrochemical Engineering Journal}

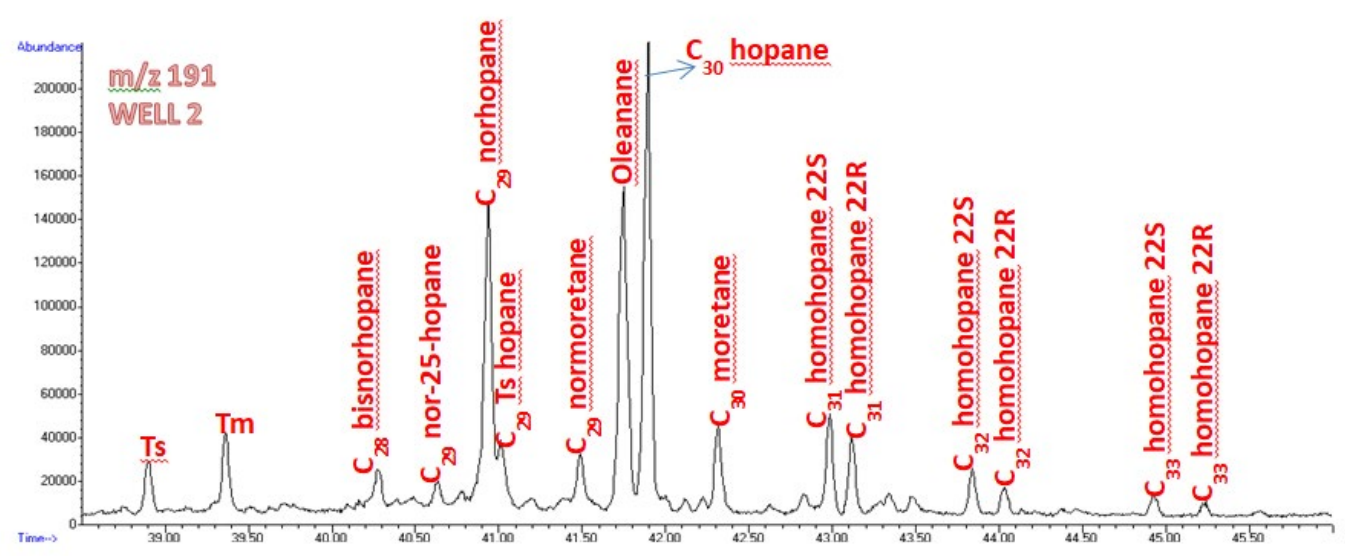

Figure 6: Mass chromatograms of studied samples showing biodegradation.

\section{Results and Discussions}

Biodegradation is the effect of bacterial activity on petroleum. Bacteria destroy normal alkane patterns, isoprenoid and biomarkers from crude oils and source rocks. Biodegradation occurs under the following conditions due to access to meteoric water with dissolved oxygen, water temperature below $70-80^{\circ} \mathrm{C}$ and in absence of hydrogen sulphide [13]. The results of biodegradation are the loss of long-chain and unbranched components, like n-alkanes which are most susceptible to biodegradation.

The process of Biodegradation of petroleum hydrocarbons is a complex process and depends on the nature and the amount of the hydrocarbons present. These Petroleum Hydrocarbons varies in their vulnerability to microbial attack. The vulnerability of petroleum hydrocarbons to microbial degradation can be mostly ranked in the following order: normal paraffins > branched paraffins $>$ small aromatics $>$ cyclic alkanes [14-15]. High molecular weight compounds, such aromatics and most biomarkers are resistant to microbial degradation [16]. Microorganisms especially bacteria are the most potent agents in petroleum degradation, and they act as main degraders of crude spill oil in the environment $[17,18]$. Numerous bacteria have been shown to feed entirely on hydrocarbons [19]. Some researchers such as Floodgate G [20] enumerated over twenty-five species of hydrocarbon degrading bacteria and fungi that were isolated from marine environment.

The biodegradation of petroleum-derived aromatic hydrocarbons and petroleum hydrocarbons in different marine environment particularly the biodegradation of alkyl aromatics in marine environment, which occurred prior to detectable biodegradation of $n$-alkane profile of the crude oil $[21,22]$. Some of the identified microorganisms found to be involved in biodegradation of the alkyl aromatics in the crude oils are: Arthrobacter, Burkholderia, Mycobacterium, Pseudomonas, Sphingomonas, and Rhodococcus, fluorescens, P. aeruginosa, Bacillus subtilis, Bacillus sp., Alcaligenes sp., Acinetobacter lwoffi, Flavobacterium sp., Micrococcus roseus, and Corynebacterium sp.

The past two decades ago has recorded successfully the studies on the biodegradation effect on the compositions of crude oil. The removal of normal alkanes in the course of crude oil degradation was reported by Winters JC [23] and these results were supported by the research work of Milner CWD, et al. [24]. Though Gas- Chromatography alone was used in this early research, it still documented the information on the removal rate of isoprenoids and normal alkanes. Nevertheless, with the invention of Gas Chromatography-Mass spectrometry, biodegradation effect on the distributions of biomarkers on oil samples has been recorded [25]. The sequence of biomarker degradation as stated by Wang Z, et al. [26] are in the following order: Diasteranes $>\mathrm{C}_{27}$ steranes $>$ tricyclic terpanes $>$ pentacyclic terpanes $>$ norhopanes $\left(\mathrm{C}_{29} \mathrm{Ts}\right)-\mathrm{C}_{29} \alpha \beta \beta$ steranes. Steranes degradation: $\mathrm{C}_{27}>\mathrm{C}_{28}>\mathrm{C}_{29}$ and Terpanes degradation: $\mathrm{C}_{35}$ $>\mathrm{C}_{34}>\mathrm{C}_{33}>\mathrm{C}_{32}>\mathrm{C}_{31}$. Abrakasa $\mathrm{S}$ [27] stated that Coastal swamp/Offshore oils are more degraded when compared to crude oils from the Greater Ughelli, Northern and Central swamp depobelts.

Various diagnostic ratios have been examined to estimate biodegradation levels in the studied samples (Table 1) and the oil-oil correlation effect with respect to biodegradation. The $(\mathrm{Pr}+\mathrm{Ph}) /\left(\mathrm{nC}_{17}+\mathrm{nC}_{18}\right)$ is a very sensitive biodegradation diagnostic ratio that increases as biodegradation trend progresses, the reason being that $(\mathrm{Pr}+\mathrm{Ph})$ show more resistance to biodegradation when compared to normal alkanes $\left(\mathrm{nC}_{17}+\mathrm{nC}_{18}\right)$. Moderately degraded oils can be 


\section{Petroleum \& Petrochemical Engineering Journal}

monitored using this diagnostic ratio [27]. The cross plot of $\mathrm{Pr} / \mathrm{Ph}$ vs $(\mathrm{Pr}+\mathrm{Ph}) /\left(\mathrm{nC}_{17}+\mathrm{nC}_{18}\right)$ presented as figure 3 , shows evidence of biodegradation in all the studied oils. The figure shows that WELL 2 is the least degraded oil while TEB 12 is the most degraded with respect to alkanes. Normal alkane degradation is best expressed by $(\mathrm{Pr}+\mathrm{Ph}) /\left(\mathrm{nC}_{17}+\mathrm{nC}_{18}\right)$. The order of degradation using this diagnostic ratio is as follows: TEB $12>$ AZU ST $>$ TEB $08>$ CCST > WELL 2 .

Hopanes biomarkers are resistant to biodegradation [4]. The ratio of $\mathrm{C}_{30} \mathrm{Hopane} /(\mathrm{Pr}+\mathrm{Ph})$ is another diagnostic ratio used in determining the biodegradation levels in crude oil samples. This diagnostic ratio increases with respect to biodegradation. It is assumed that during biodegradation, Pristane and Phytane decreases; remaining the stable hopanes which are resistant to biodegradation [27]. Figure 4 shows that AZU ST is the most degraded oil while TEB 08 is the least degraded oil. The ranking of degradation using $\mathrm{C}_{30}$ Hopane/( $\left.\mathrm{Pr}+\mathrm{Ph}\right)$ follows the order: AZU ST > WELL $2>$ TEB $12>$ CCST $>$ TEB 08 .

The diagnostic ratio $\mathrm{C}_{29}$ Norhopane $/ \mathrm{C}_{30}$ Hopane can be used for both organic source input and biodegradation assessment. High $\mathrm{C}_{29}$ Norhopane $/ \mathrm{C}_{30}$ Hopane ratio is indicative of marine organic matter rich in evaporates and carbonates (anhydride, gypsum, halite and calcite) deposited under a reducing condition [28]. Applying same parameter to biodegradation, Figure 5 shows the biodegradation assessment using $\mathrm{C}_{29}$ Norhopane/ $\mathrm{C}_{30}$ Hopane ratio. This diagnostic ratio infers a 25-norhopane increase through demethylation by microrganisms during biodegradation. 25norhopanes are significantly resident in degraded oil and can be used in biodegradation assessment [29]. This diagnostic ratio also increases with respect to biodegradation. Figure 5 shows a close correlation in all studied samples, except WELL 2 with a ratio of 0.43 (Table 1). Biodegradation ranking based on this ratio infers that AZU ST and TEB 12 are the most degraded oils in terms of the 25-Norhopanes predominance while WELL 2 ranks the least degradation. The 25-Norhopanes are reliably used in assessment of degraded oils. TEB $12>$ AZU ST > CCST > TEB $08>$ WELL 2; show the ranking order of degradation using $\mathrm{C}_{29}$ Norhopane/ $\mathrm{C}_{30}$ Hopane (Note: TEB 12 and AZU ST have similar value). $\mathrm{M} / \mathrm{z} 191$ reconstructed chromatograms for studied samples presented as Figure 6 show their different levels of biodegradation.

\section{Conclusion}

This research evaluated the different degrees of biodegradation using various biodegradation diagnostic ratios for the studied samples. The results of bulk property, biomarker analysis of crude oils suggest that all studied samples showed different levels of biodegradation. The
$(\mathrm{Pr}+\mathrm{Ph}) /\left(\mathrm{nC}_{17}+\mathrm{nC}_{18}\right) \quad$ and $\quad \mathrm{C}_{29}$ Norhopane $/ \mathrm{C}_{30}$ Hopane diagnostic ratios show that among the coastal swamp oils, TEB 12 and AZU ST are the most degraded while WELL 2 ranks the least degraded. These diagnostic ratios may be useful in profiling oils at different biodegradation levels.

\section{Acknowledgement}

Dr. Selegha Abrakasa and Mr. Cashmoney Anyamalem are highly appreciated by the authors for their immense contributions and qualitative assistance in the course of this work. Authors express sincere appreciation to Nigerian Agip Oil Company (NAOC) for granting us access to the crude oil samples.

\section{Nomenclatures}

\begin{tabular}{|c|c|}
\hline AZU ST & Azuzuama Well 5 Tubing \\
\hline CCST & Clough Creek Well 5 Tubing \\
\hline TEB 12 & Tebidaba Well 12 \\
\hline TEB 08 & Tebidaba Well 8 \\
\hline WELL 2 & Tebidaba Well GSS \\
\hline Pr & Pristane \\
\hline Ph & Phytane \\
\hline
\end{tabular}

\section{References}

1. Volkman JK, Maxwell JR (1984) Biological Marker: A monograph. Elsevier Armstedam, pp: 856.

2. Miiller DE, Holba AG, Huges WB (1987) Effects of biodegradation on crude oils. In: Meyer RF (Ed.), Exploration for heavy crude oil and natural bitumen. American Association of Petroleum Geologists Studies, pp: 233-241.

3. Rheinheimer G (1984) Aquatic microbiology. Wiley, London, pp: 1973.

4. Chosson P, Lanau C, Connan J, Dessort D (1991) Biodegradation of refractory hydrocarbon biomarkers from petroleum under laboratory conditions. Nature 351: 640-642.

5. Seifert WK, Moldowan JM, Demaison GJ (1984) Source correlation of biodegraded oils. Organic Geochemistry 6: 633-643.

6. Peters K, Walters C, Moldowan JM (2005) The biomarker guide. Cambridge University Press, UK, pp: 1155.

7. Peters K, Moldowan J (1993) The Biomarker Guide: Interpreting Molecular Fossils in Petroleum and Ancient 


\section{Petroleum \& Petrochemical Engineering Journal}

Sediments. Prentice Hall, New Jersey, USA, pp: 363.

8. Sonibare O,Alimi H,Jarvie D, Ehinola OA (2008) Origin and occurrence of crude oil in the Niger delta Nigeria. Journal of Petroleum Science and Engineering 61(2-4): 99-107.

9. Ekweozor CM, Okogun JI, Ekong DEU, Maxwell JR (1979) Preliminary organic geochemical studies of samples from the Niger delta (Nigeria), Analyses of crude oils for triterpanes. Chemical Geology 27(1-2): 11-28.

10. Eneogwe C, Ekundayo O (2003) Geochemical correlation of crude oils in the NW Niger Delta, Nigeria. Journal of Petroleum Geology 26(1): 95-103.

11. Abrakasa S (2006) Newly identified Molecular Marker Compound in Some Nigerian oils. Nigeria Journal of chemical Research 11: 15-21.

12. Onojake MC, Abrakasa S, Osuji LC (2015) Chemometric representation of molecular marker data of some Niger Delta crude oils. Egyptian Journal of Petroleum 24(2): 139-143.

13. Connan J (1984) Biodegradation of crude oils in reservoirs. Brooks J, Welte D (Eds.) Advances in Petroleum Geochemistry. Academic Press, Elsevier, Volume 1, pp: 229-335.

14. Ulrici W (2000) Contaminated soil areas, different countries and contaminants, monitoring of contaminants. In: Rehm HJ, Reed G (Eds.), Biotechnology: Environmental Process. ${ }^{\text {nd }}$ (Edn.), Willey, pp: 5-41.

15. Perry JJ (1984) Microbial metabolism of cyclic alkanes. In: Atlas RM (Ed.), Petroleum Microbiology. Macmillan Publishing Co., New York, USA, pp: 61-98.

16. Atlas R, Bragg J (2009) Bioremediation of marine oil spills: when and when not-the Exxon Valdez experience. Microbial Biotechnology 2(2): 213-221.

17. Rahman KSM, Rahman TJ, Kourkoutas Y, Petsas I, Marchant R, et al. (2003) Enhanced bioremediation of $\mathrm{n}$-alkane in petroleum sludge using bacterial consortium amended with rhamnolipid and micronutrients. Bioresour Technol 90(2): 159-168.

18. Brooijmans RJW, Pastink MI, Siezen RJ (2009) Hydrocarbon-degrading bacteria: the oil-spill clean-up crew. Microbial Biotechnology 2(6): 587-594.
19. Yakimov MM, Timmis KN, Golyshin PN (2007) Obligate oil-degrading marine bacteria. Current Opinion in Biotechnology 18(3): 257-266.

20. Floodgate G (1984) The fate of petroleum in marine ecosystems. In: Atlas RM (Ed.), Petroleum Microbiology. Macmillan Publishing Co., New York, USA, pp: 355-398.

21. Jones DM, Douglas AG, Parkes RJ, Taylor J, Giger W, et al. (1983) The recognition of biodegraded petroleumderived aromatic hydrocarbons in recent marine sediments. Marine Pollution Bulletin 14(3): 103-108.

22. Adebusoye SA, Ilori MO, Amund O0, Teniola OD, Olatope SO (2007) Microbial degradation of petroleum hydrocarbons in a polluted tropical stream. World Journal of Microbiology and Biotechnology, 23(8): 11491159.

23. Winters JC, Williams JA (1969) Microbiological alteration of crude oil in the reservoir. In: Symposium of Petroleum Transformation in Geologic Environments. American Chemical Society, Division of Fuel Chemistry, Paper PETR 86: E22-E31.

24. Milner CWD, Rogers MA, Evans CR (1977) Petroleum transformations in reservoirs. Journal of Geochemical Exploration 7: 101-153.

25. Philip RP, Lewis CA (1987) Organic geochemistry of biomarkers. Ann Rev Earth Planet Sci 15: 363-395.

26. WangZ, StoutAS, Fingas M (2006) Forensic Fingerprinting of Biomarkers for Oil Spill Characterization and Source Identification. Environmental Forensics 7(2): 105-146.

27. Abrakasa S, Nwankwo C (2019) Biodegradation ranking show Offshore and Coastal Swamp oils more degraded in Niger Delta Basin. Journal of Research in Environmental and Earth Science 5(1): 27-35.

28. Mohialdeen IMJ, Hakimi MH, Al-Beyati FM (2006) Geochemical and petrographic characterization of Late Jurassic-Early Cretaceous Chia Gara Formation in Northern Iraq: palaeoenvironment and oil generation potential. Marine and Petroleum Geology 43: 166-177.

29. Huang H, Larter S, Bowler BF, Oldenburg TB (2014) A dynamic biodegradation model suggested by petroleum compositional gradients within reservoir columns from the Liaohe basin, NE China. Organic Geochemistry 35(3): 299-316. 